\title{
Crizotinib in non-small cell lung cancer
}

\author{
Nawfel Mellas ${ }^{1^{\star}}$, Fatimzahra Hijri $^{1}$, Zineb Benbrahim $^{1}$, Omar El Mesbahi $^{1}$, Nabil Ismaili $^{2}$ \\ ${ }^{1}$ Department of Medical Oncology, Hassan II University Hospital, Fez, Morocco; *Corresponding Author: $\underline{\text { mellasnawfel@yahoo.fr }}$ \\ ${ }^{2}$ Oncology Center, Medical Oncology, University Hospital Mohammed VI, Marrakech, Morocco \\ Received 9 December 2013; revised 9 January 2014; accepted 21 January 2014 \\ Copyright (c) 2014 Nawfel Mellas et al. This is an open access article distributed under the Creative Commons Attribution License, \\ which permits unrestricted use, distribution, and reproduction in any medium, provided the original work is properly cited. In accor- \\ dance of the Creative Commons Attribution License all Copyrights (c) 2014 are reserved for SCIRP and the owner of the intellectual \\ property Nawfel Mellas et al. All Copyright (c) 2014 are guarded by law and by SCIRP as a guardian.
}

\section{ABSTRACT}

Chemotherapy and targeted therapy remain the cornerstone of treatment of locally advanced and metastatic non-small cells lung cancer (NSCLC). Given the intrinsic chemoresistance of tumor cells, new treatment options have been developped. The knowledge of the molecular mechanisms of tumor biology, and signal transduction pathways activating cancer cells led to the identification of a new targeted therapy such as Crizotinib. The small molecule Crizotinib is a selective inhibitor of the receptor tyrosine kinase ALK (anaplastic lymphoma kinase) and its oncogenic variants (ALK fusion gene and some mutations of ALK). Phases I and II trials showed the efficacy of Crizotinib in the treatment of locally advanced and metastatic NSCLC expressing ALK. Thereafter, randomized Phase III trial confirmed the significant superiority of Crizotinib versus standard chemotherapy in terms of progression free survival and objective response with good tolerance; therefore, it has been approved by the Food and Drug Administration (FDA) as the standard treatment for locally advanced and metastatic ALK-positive NSCLC.

\section{KEYWORDS}

NSCLC; Crizotinib; Metastatic NSCLC; ALK; Chemotherapy

\section{INTRODUCTION}

Crizotinib is a new targeted molecule [1,2]. It has been shown to be effective in the treatment of ALK-positive locally advanced and metastatic non-small cell lung cancer (NSCLC) [3,4], more specifically in adenocarcinoma subtype [5]. Crizotinib was recently approved by the
FDA as a standard treatment for ALK-positive locally advanced and metastatic NSCLC [6].

The Crizotinib has been tested in patients with metastatic NSCLC, the tumor which has a genetic defect on chromosome 2, resulting in the fusion of two genes, ALK and EML4 (echinoderm microtubule-associated proteinlike 4) [7-9]. This DNA rearrangement leads to the production of ALK protein which enhances cancer cells proliferation. This protein is involved in the ontogenesis of $2 \%$ to $7 \%$ of lung adenocarcinomas [3,4]. Crizotinib inhibits the activity of this protein by targeting the ALK part [5,7]. This mechanism of action of Crizotinib explains largely the effectiveness of this new treatment in patients whose tumors express ALK. In patients with locally advanced and metastatic NSCLC expressing ALK, Phase I and II trials showed highly objective responses and acceptable tolerability with crizotinib [4,5]. This opens the new era of personalized therapeutic treatment.

\section{THE ALK SIGNALING PATHWAY}

The ALK signaling pathway plays a major role in the cell proliferation, differentiation and cell survival. ALK protein is a part of the family of insulin receptor [10]. It is a receptor with known ligands; pleiotrophin and midkine. In the presence of its legend, the ALK sends a signal to cell proliferation and differentiation, and in the absence of legend, it sends a signal to cell death [11].

Since 1994, this pathway is known to be involved in the development of anaplastic large cell lymphoma of the child [12]. Other translocations have been described in inflammatory myofibroblastic tumors. Another mechanism involving gene amplification of ALK is associated with subgroups of familial neuroblastoma [13].

\section{ALK PATHWAY IN NSCLC}

Genetic defect on chromosome 2 led to the fusion of two genes, EML4 (echinoderm microtubule-associated 
protein-like 4) and ALK (anaplastic lymphoma kinase) giving rise to a fusion gene EML4-ALK [7]. These genes were described for the first time in 2007 by a Japanese team. This rearrangement inserted effective inversion part (variable length) of EML4 N-terminal domain within the ALK gene. This insertion is made at the exon 20 of the EML4 juxtaposing inserting the entire gene to the cytoplasmic area comprising the ALK tyrosine kinase function [8]. This rearrangement of DNA leads to the generation of a chimeric protein, ALK protein, EML4ALK that has tyrosine kinase activity. This chimeric protein is characterized by constitutive activation of the ALK tyrosine kinase, resulting and in cell proliferation and resistance to apoptosis.

This protein is an oncogene involved in $2 \%-7 \%$ of lung cancers. It is seen especially in non-smokers or light smokers with adenocarcinoma form. Patients with EML4ALK rearrangement are characterized by an excess of liver metastases, pleural and pericardial invasion and probably an excess of brain metastases [14]. Rearrangement of ALK gene can be detected by fluorescence in situ hybridization (FISH) and the transcripts by RT-PCR in molecular biology. The fusion transcript is expressed and its detection is possible by immunohistochemical methods.

\section{KEY DATA PHARMACOGENETICS OF CRIZOTINIB}

The Crizotinib is a selective inhibitor molecule receptor of tyrosine kinase (RTK) ALK and its oncogenic variants (ALK fusion gene and some mutations of ALK) [7-9]. It is also an inhibitor of the RTKs hepatocyte growth factor (HGFR or c-Met) [4,9].

The Crizotinib showed a concentration-dependent inhibition of the kinase activity of ALK and c-Met in biochemical assays, and inhibited the phosphorylation and the function dependent of kinases in cellular assays. It has also a potent and selective inhibition of the growth and induced apoptosis in tumor cell lines with ALK fusion variants (EML4-ALK or NPM-ALK) or with an ALK gene locus amplification or c-Met.

Hence its effectiveness as a treatment of ALK-positive advanced stage NSCLC $[4,6,8,9]$.

\section{PHARMACOKINETICS AND METABOLISM}

Optimal dose of Crizotinib was 250 mg twice daily and the molecule is metabolized primarily in the liver. Following administration of a single dose of $250 \mathrm{mg}$ of radiolabeled Crizotinib to healthy patient, $63 \%$ and $22 \%$ of the administered dose was recovered respectively in the feces and urine. The Crizotinib unchanged represented approximately $53 \%$ and $1.3 \%$ of the administered dose recovered in the feces and urine [6].

\section{CRIZOTINIB DEVELOPMENT IN THE TREATMENT OF ADVANCED NSCLC}

The effectiveness of Crizotinib in the treatment of ALK-positive NSCLC has been proven by several Phase I, Phase II and one Phase III trials. Other Phases III trials are underway to confirm this benefit.

\subsection{Phase I Trials}

The Phase I study, PROFILE 1001 including 37 patients with various advanced stage tumors, including colorectal cancer (six patients), sarcoma (four patients) and NSCLC (three patients), refractory to standard treatments, aimed to assess the maximum tolerated dose [4].

Given the important activity of crizotinib in 2 patients with NSCLC with ALK rearrangement, this Phase I study has been extended with a specific cohort. The extension of this Phase I trial was published in October 2010 in the New England Journal of Medicine [15]. After screening 1500 patients with NSCLC in search of ALK rearrangement by FISH, the investigators identify 82 (5, $5 \%)$ patients with advanced ALK positive NSCLC.

The ALK positive population was relatively young (median age 51 years) consisted of 35\% asian, small or non-smokers (94\%), mainly with adenocarcinoma (96\%) patients who had received at least one prior chemotherapy regimen in $94 \%$ of cases.

At 6.4 months of treatment (median duration of treatment), $57 \%$ of patients had partial or complete response (partial response in 46 patients and one patient in complete response) and 33\% had stabile disease.

The update of this Phase I study was recently published [16]. 143 patients were evaluable. 60.8\% (95\% CI 52.3 - 68.9) had an objective response (87 of 143 patients), including three complete responses and 84 partial responses. The median duration of response was 49.1 weeks (95\% CI 39.3 - 75.4). This response is largely independent of sex, age, condition and the number of previous treatments. The median progression-free survival (PFS) was 9.7 months (95\% CI 7.7-12.8). The median overall survival (OS) was not yet mature, but an estimate of survival at 6 months and 12 months was 87.9\% (95\% CI 81.3-92.3) and 74.8\% (66.4 - 81.5), respectively.

\subsection{Phase II Trials}

A non-comparative Phase II multicenter single-arm trial (PROFILE 1005) investigated the efficacy and safety of Crizotinib administered to patients with ALK-positive advanced NSCLC progressing after chemotherapy treatment [5]. Until June 2011, tolerance was evaluated in 439 patients and tumor response was assessed in 255 
patients. The median age is 53 years. The majority were women (53\%), non-smokers (65\%), diagnosed with adenocarcinoma (92\%), having an ECOG performance status of 0 - 2 (83\%) and received $\geq 2$ lines of chemotherapy (85\%). The median duration of treatment was 25 weeks (treatment ongoing in $77 \%$ ). The rate of disease control at 12 weeks was $85 \%$ (95\% CI: 80 - 89), the median duration of response was 43 weeks (96\% CI 36 - 50) and the median PFS was 8.5 months (95\% CI: 6.2 - 9.9). The side effects most frequently reported were visual disturbances (50\%), nausea (46\%), vomiting (39\%) and diarrhea (35\%), the majority of which were grade $1-2.29$ patients $(6.6 \%)$ had treatment-related side effects, including dyspnea and pneumonia (0.9\%), febrile neutropenia and renal cyst (0.5\%). Based on this study, Crizotinib demonstrated a benefit in response rate and PFS with good tolerance and improvement of symptoms. These results confirm those of the Phase I trial, and provide strong evidence on the effectiveness of Crizotinib in locally advanced and metastatic ALK-positive NSCLC.

\subsection{Phase III Trials}

Based on the data from Phase I and II trials, Phase III trials have been conducted to assess the benefit of Crizotinib in patients with advanced stage NSCLC with ALK rearrangement.

PROFILE 1007 is a randomized Phase III trial including 347 patients with stage IIIb or IV ALK-positive NSCLC previously treated with platinum-based chemotherapy. In this study, two arms were randomized to receive Crizotinib or standard second line chemotherapy: Pemetrexed or Docetaxel [17]. The primary endpoint was PFS and the secondary endpoint was overall survival (OS). In this study, the Crizotinib has demonstrated its superiority over docetaxel and pemetrexed; the median PFS was 7.7 months in the Crizotinib arm versus 3 months in the chemotherapy arm $(\mathrm{P}<0.0001)$. Crizotinib comparing each drug separately, the median PFS was 7.7 months in the Crizotinib arm versus 4.2 months in the pemetrexed arm $(\mathrm{P}=0.0004)$ versus 2.6 months in the docetaxel arm $(\mathrm{P}<0.0001)$. In addition, the response rate to Crizotinib was high: $65.3 \%$ in Crizotinib arm versus $19.3 \%$ in the chemotherapy arm $(\mathrm{P}<0.0001)$. Comparing Crizotinib to each drug separately, the response rate to crizotinib was $65.7 \%$ versus $29.3 \%$ in the pemetrexed arm versus $6.9 \%$ in the docetaxel arm. An interim analysis showed no benefit in OS (111 patients underwent a crossover to crizotinib arm), but the results are still immature. The safety profile was acceptable and the quality of life was higher for patients treated with Crizotinib $(\mathrm{P}<$ 0.0001). So, the study profile 1007 is the first Phase III randomized trial comparing crizotinib with standard chemotherapy in patients with locally advanced or metastatic ALK positive NSCLC, having demonstrated a benefit of Crizotinib in PFS compared with 2nd line chemotherapy; pemetrexed or docetaxel, and thus Crizotinb have become the standard 2nd line treatment, in patietns with ALK positive NSCLC.

Given these very encouraging results in second line, a randomized Phase III in first-line is being set underway (PROFILE 1014) with the aim to confirm the superiority of Crizotinib compared to standard first line chemotherapy. This is a Phase III study randomizing more than 300 patients with locally advanced or metastatic NSCLC with EML4-ALK translocation to Crizotinib or to a standard first line chemotherapy doublet pemetrexed plus cisplatin or carboplatine [18].

\section{SAFETY}

In preclinical studies, Crizotinib was accumulating in the eye and its annexes (Uvea, lacrimal glands) with a half-life of up to 576 hours [3]. Nearly $60 \%$ of patients had visual disorders such double vision, decreased visual acuity, floating vitreous visual field. These disorders are in the vast majority of cases of grade 1 (98\% of cases) and do not require special care outside monitoring [5,17]. Other common side effects $(\geq 30 \%)$ are gastrointestinal toxicity with diarrhea, nausea and vomiting (1\%, grade 2 ), the occurrence of peripheral edema and asthenia [17]. The grade 3/4 toxicities were the alteration of liver function in $6 \%$ of patients, hypokalemia and dyspnea in less than $4 \%$ of cases, acute pneumonia in less than $2 \%$ of patients [17]. Abnormal heart rhythm as bradycardia and QT prolongation have also been reported $[17,19]$.

\section{RESISTANCE TO CRIZOTINIB}

Despite the high response rate, $50 \%$ of patients with ALK gene rearrangement receiving Crizotinib progress 10 months after initiation of treatment [20,21]. Japanese researchers have shown through analysis in Phase I trial, the presence of two mutations acquired C1156Y L1196M and in patients with ALK gene rearrangement in Crizotinib progressing after an initial response. Other investigators have confirmed that mutations C1156Y and L1196M are responsible for resistance to Crizotinib and identified other mutations in the tyrosine kinase domain responsible for the decreased activity of Crizotinib. Several recent studies have shown that mutations of the Kras or EGFR gene or loss of ALK gene rearrangement have acquired resistance to Crizotinib [20-23]. Extensive research retailers mechanisms of resistance to Crizotinib are needed to improve the therapeutic benefit results.

\section{CONCLUSIONS}

The Crizotinib is a major therapeutic advance in the treatment of NSCLC with ALK gene rearrangement, 
with an unprecedented response rate of $57 \%$ in eight weeks. With such results, Crizotinib has been an accelerated procedure in the United States to obtain a marketing authorization.

Phase I/II and recently Phase III randomized trials had demonstrated a significant improvement in PFS in the second line metastatic sitting with crizotinib compared with standard chemotherapy, allowing Crizotinib to become the new standard of care in ALK positive patients in the 2nd line.

These promising results should not obscure the fact that only 5\% of NSCLC may benefit from treatment with Crizotinib and the safety profile is not yet clearly established requiring more pharmacovigilance data.

Also the emergence of resistance is another issue of the development of Crizotinib, requiring further research to better understand these mechanisms of resistance and improve patient outcomes benefit.

\section{REFERENCES}

[1] Scagliotti, G.V., Parikh, P., Von Pawel, J., Biesma, B., Vansteenkiste, J., Manegold, C., Serwatowski, P., Gatzemeier, U., Digumarti, R., Zukin, M., Lee, J.S., Mellemgaard, A., Park, K., Patil, S., Rolski, J., Goksel, T., de Marinis, F., Simms, L., Sugarman, K.P. and Gandara, D. (2008) Phase III study comparing cisplatin plus gemcitabine with cisplatin plus pemetrexed in chemotherapy-naive patients with advanced-stage non-small-cell lung cancer. Journal of Clinical Oncology, 26, 3543-3551. http://dx.doi.org/10.1200/JCO.2007.15.0375

[2] Shepherd, F.A., Rodrigues, P.J., Ciuleanu, T., Tan, E.H., Hirsh, V., Thongprasert, S., Campos, D., Maoleekoonpiroj, S., Smylie, M., Martins, R., van Kooten, M., Dediu, M., Findlay, B., Tu, D., Johnston, D., Bezjak, A., Clark, G., Santabárbara, P., Seymour, L., National Cancer Institute of Canada Clinical Trials Group. (2005) Erlotinib in previously treated non-small-cell lung cancer. New England Journal of Medecine, 353, 123-132. http://dx.doi.org/10.1056/NEJMoa050753

[3] Yamazaki, S., Vicini, P., Shen, Z., Zou, H.Y., Lee, J., Li, Q., Christensen, J.G., Smith, B.J. and Shetty, B. ((2012) Pharmacokinetic/pharmacodynamic modeling of crizotinib for anaplastic lymphoma kinase inhibition and antitumor efficacy in human tumor xenograft mouse models. Journal of Pharmacology and Experimental Therapeutics, 340, 549-557.

http://dx.doi.org/10.1124/jpet.111.188870

[4] Kwak, E.L., Camidge, D.R., Clark, J., Shapiro, G.I., Maki, R.G., Ratain, M.J., Solomon, B., Bang, Y., Ou, S. and Salgia, R. (2009) Clinical activity observed in a Phase I dose escalation trial of an oral c-met and ALK inhibitor, PF-02341066. Journal of Clinical Oncology, 27, Abst. 3509.

[5] Crino, L., Kim, D., Riely, G.J., Janne, P.A., Blackhall, F.H., Camidge, D.R., et al. (2011) Initial Phase II results with crizotinib in advanced ALK-positive non-small cell lung cancer (NSCLC): PROFILE 1005. Journal of Clinical Oncology, 29, Abst. 7514.

[6] Crizotinib [package insert]. (2011) http://www.accessdata.fda.gov/drugsatfda_docs/label/201 1/202570s000lbl.pdf

[7] Ding, L., Getz, G., Wheeler, D.A., Mardis, E.R., McLellan, M.D., Cibulskis, K., et al. (2008) Somatic mutations affect key pathways in lung adenocarcinoma. Nature, 455, 1069-1075. http://dx.doi.org/10.1038/nature07423

[8] Soda, M., Choi, Y.L., Enomoto, M., Takada, S., Yamashita, Y., Ishikawa, S., Fujiwara, S.-I., Watanabe, H., Kurashina, K., Hatanaka, H., Bando, M., Ohno, S., Ishikawa, Y., Aburatani, H., Niki, T., Sohara, Y., Sugiyama, Y. and Mano, H. (2007) Identification of the transforming EML4ALK fusion gene in non-small-cell lung cancer. Nature, 448, 561-566. http://dx.doi.org/10.1038/nature05945

[9] Inamura, K., Takeuchi, K., Togashi, Y., Nomura, K., Ninomiya, H., Okui, M., Satoh, Y., Okumura, S., Nakagawa, K., Soda, M., Choi, Y.L., Niki, T., Mano, H. and Ishikawa, Y. (2008) EML4-ALK fusion is linked to histological characteristics in a subset of lung cancers. Journal of Thoracic Oncology, 3, 13-17. http://dx.doi.org/10.1097/JTO.0b013e31815e8b60

[10] Palmer, R.H., Vernersson, E., Grabbe, C. and Hallberg, B. (2009) Anaplastic lymphoma kinase: Signalling in development and disease. Biochemical Journal, 420, 345. http://dx.doi.org/10.1042/BJ20090387

[11] Mourali, J., Bénard, A., Lourenco, F.C., Monnet, C., Greenland, C., Moog-Lutz, C., Racaud-Sultan C, Gonzalez-Dunia, D., Vigny, M., Mehlen, P., Delsol, G. and Allouche, M. (2006) Anaplastic lymphomakinase is a dependence receptor whose proapoptotic functions are activated by caspase cleavage. Molecular and Cellular Biology, 26, 6209-6222. http://dx.doi.org/10.1128/MCB.01515-05

[12] Fallet, V., Toper, C., Antoine, M., Cadranel, J. and Wislez, M. (2012) Crizotinib, modalités pratiques d'un traitement personnalisé. Bulletin de Cancer, 99, 787-791.

[13] Janoueix-Lerosey, I., Lequin, D., Brugières, L., Ribeiro, A., de Pontual, L., Combaret, V., Raynal, V., Puisieux, A., Schleiermacher, G., Pierron, G., Valteau-Couanet, D., Frebourg, T., Michon, J., Lyonnet, S., Amiel, J. and De- lattre, O. (2008) Somatic and germline activating mutations of the ALK kinase receptor in neuroblastoma. Nature, 455, 967-970. http://dx.doi.org/10.1038/nature07398

[14] Camidge, D.R. and Doebele, R.C. (2012) Treating ALKpositive lung cancer early successes and future challenges. Nature Reviews Clinical Oncology, 3, 268-277. http://dx.doi.org/10.1038/nrclinonc.2012.43

[15] Kwak, E.L., Bang, Y.J., Camidge, D.R., Shaw, A.T., Solomon, B., Maki, R.G., Ou, S.H., Dezube, B.J., Jänne, P.A., Costa, D.B., Varella-Garcia, M., Kim, W.H., Lynch, T.J., Fidias, P., Stubbs, H., Engelman, J.A., Sequist, L.V., Tan, W., Gandhi, L., Mino-Kenudson, M. Wei, G.C., Shreeve, S.M., Ratain, M.J., Settleman, J., Christensen, J.G., Haber, D.A., Wilner, K., Salgia, R., Shapiro, G.I., Clark, J.W. and Iafrate, A.J. (2010) Anaplastic lymphoma kinase inhibition in non-small cell lung cancer. New England 
Journal of Medecine, 363, 1693-1703. http://dx.doi.org/10.1056/NEJMoa1006448

[16] Camidge, D.R., Bang, Y.J, Kwak, E.L, Iafrate, A.J., Varella-Garcia, M., Fox, S.B., Riely, G.J., Solomon, B., Ou, S.H., Kim, D.W., Salgia, R., Fidias, P., Engelman, J.A., Gandhi, L., Jänne, P.A., Costa, D.B., Shapiro, G.I., Lorusso, P., Ruffner, K., Stephenson, P., Tang, Y., Wilner, K., Clark, J.W. and Shaw, A.T. (2012) Activity and safety of crizotinib in patients with ALK-positive non-small-cell lung cancer: Updated results from a Phase 1 study. Lancet Oncology, 13, 1011-1019. http://dx.doi.org/10.1016/S1470-2045(12)70344-3

[17] Shaw, A.T., Kim, D.W., Nakagawa, K., Seto, T., Crinó, L., Ahn, M.J., De Pas, T., Besse, B., Solomon, B.J., Blackhall, F., Wu, Y.L., Thomas, M., O’Byrne, K.J., Moro-Sibilot, D., Camidge, D.R., Mok, T., Hirsh, V., Riely, G.J., Iyer, S., Tassell, V., Polli, A., Wilner, K.D. and Jänne, P.A. (2013) Crizotinib versus chemotherapy in advanced ALKpositive lung cancer. New England Journal of Medecine, 368, 2385-2394. http://dx.doi.org/10.1056/NEJMoa1214886

[18] Lee, J.O., Kim, T.M., Lee, S.H., Kim, D.W., Kim, S., Jeon, Y.K., Chung, D.H., Kim, W.H., Kim, Y.T., Yang, S.C., Kim, Y.W., Heo, D.S. and Bang, Y.J. (2011) Anaplastic lymphoma kinase translocation: A predictive biomarker of pemetrexed in patients with non-small cell lung cancer. Journal of Thoracic Oncology, 6, 1474-1480. http://dx.doi.org/10.1097/JTO.0b013e3182208fc2

[19] Ou, S.H., Azada, M., Dy, J. and Stiber, J.A. (2011) Asymptomatic profound sinus bradycardia (heart rate $\leq 45$ ) in non-small cell lung cancer patients treated with crizotinib. Journal of Thoracic Oncology, 6, 2135-2137. http://dx.doi.org/10.1097/JTO.0b013e3182307e06
[20] Zhang, S., Wang, F., Keats, J., Zhu, X., Ning, Y., Wardwell, S.D., Moran, L., Mohemmad, Q.K., Anjum, R., Wang, Y., Narasimhan, N.I., Dalgarno, D., Shakespeare, W.C., Miret, J.J., Clackson, T. and Rivera, V.M. (2011) Crizotinib-resistant mutants of EML4-ALK identified through an accelerated mutagenesis screen. Chemical Biology and Drug Design, 78, 999-1005.

http://dx.doi.org/10.1111/j.1747-0285.2011.01239.x

[21] Doebele, R.C., Pilling, A.B., Aisner, D.L., Kutateladze, T.G., Le, A.T., Weickhardt, A.J., Kondo, K.L., Linderman, D.J., Heasley, L.E., Franklin, W.A., Varella-Garcia, M. and Camidge, D.R. (2012) Mechanisms of resistance to crizotinib in patients with ALK gene rearranged nonsmall cell lung cancer. Clinical Cancer Research, 18, 1472-1482. http://dx.doi.org/10.1158/1078-0432.CCR-11-2906

[22] Katayama, R., Shaw, A.T., Khan, T.M., Mino-Kenudson, M., Solomon, B.J., Halmos, B., Jessop, N.A., Wain, J.C., Yeo, A.T., Benes, C., Drew, L., Saeh, J.C., Crosby, K., Sequist, L.V., Iafrate, A.J. and Engelman, J.A. (2012) Mechanisms of acquired crizotinib resistance in ALK-rearranged lung cancers. Science Translational Medicine, 4, 120ra17.

[23] Sasaki, T., Koivunen, J., Ogino, A., Yanagita, M., Nikiforow, S., Zheng, W., Lathan, C., Marcoux, J.P., Du, J., Okuda, K., Capelletti, M., Shimamura, T., Ercan, D., Stumpfova, M., Xiao, Y., Weremowicz, S., Butaney, M., Heon, S., Wilner, K., Christensen, J.G., Eck, M.J., Wong, K.K., Lindeman, N., Gray, N.S., Rodig, S.J. and Jänne, P.A. (2011) A novel ALK secondary mutation and EGFR signaling cause resistance to ALK kinase inhibitors. Cancer Research, 71, 6051-6060.

http://dx.doi.org/10.1158/0008-5472.CAN-11-1340 